\title{
Pengembangan Nilai-Nilai Karakter Religius Berbasis Kearifan Lokal pada Siswa MI
}

\author{
Tri Rahayu \\ STIT Misbahul Ulum Gumawang \\ Email korespondensi: trirahayusabiq@gmail.com
}

\begin{abstract}
This research is motivated by the phenomenon of erasing public knowledge about the local wisdom that has become their character and their philosophy of life, namely batik. Therefore, efforts should be made to continue to explore and protect local wisdom. This research is a qualitative descriptive study with a psychoeducational approach. The research subjects were the principal, the batik teacher, the school supervisor and the pupils of classes V and VI. Data collection techniques include observation, interviews and documentation. The technique of data analysis involves collecting data, reducing the data, presenting the data and drawing conclusions. From this study it was found that the learning process based on local batik wisdom at MI Ma'arif Giriloyo I was carried out throughout the planning phase (covering annual programs, semester programs, syllabuses and lesson plans); implementation includes basic preliminary activities (covering exploration, development, confirmation) and closure; assessment of learning through observation, self-assessment and peer review. While the values of a religious character developed in learning based on the local wisdom of batik at MI Ma'arif Giriloyo I include: first, through the creation of batik patterns in the form of messages and prayers or d hopes for Allah SWT. Second, the development of the religious character of students is integrated into the implementation of classroom learning consisting of preliminary, core and closing activities.
\end{abstract}

Keyword: Value of Religious Character, Culture Locale, Batik

\section{Abstrak}

Penelitian ini dilatarbelakangi fenomena semakin memudarnya pengetahuan masyarakat tentang kearifan lokal yang telah menjadi karakter dan filosofi hidup mereka, yaitu membatik. Oleh karena itu, perlu ada upaya untuk terus menggali dan memproteksi kearifan lokal. Penelitian ini merupakan penelitian deskriptif kualitatif dengan pendekatan psikologi pendidikan. Subjek penelitian adalah Kepala Sekolah, guru mata pelajaran batik, Pengawas Sekolah serta siswa kelas $V$ dan kelas VI. Teknik pengumpulan datanya meliputi observasi, wawancara, dan dokumentasi. Adapun teknik analisis data melalui pengumpulan data, reduksi data, penyajian data serta penarikan kesimpulan. Dari penelitian ini diperoleh hasil bahwa proses pembelajaran berbasis kearifan lokal membatik di MI Maarif Giriloyo I dilaksanakan melalui tahap perencanaan (mencakup program tahunan, program semester, silabus, dan RPP); pelaksanaan terdiri atas kegiatan pendahuluan, inti (meliputi eksplorasi, elaborasi, konfirmasi), 
dan penutup; evaluasi pembelajaran melalui observasi, penilaian diri, dan penilaian antarteman. Sedangkan nilai-nilai karakter religius yang dikembangkan dalam pembelajaran berbasis kearifan lokal membatik di MI Maarif Giriloyo I antara lain: pertama, melalui penciptaan motifbatik sebagai pesan dan doa atau harapan yang ditujukan kepada Allah SWT. Kedua, pengembangan karakter religius siswa terintegrasi dalam pelaksanaan pembelajaran di kelas terdiri atas kegiatan pendahuluan, inti, dan penutup.

Kata kunci: Nilai Karakter Religius, Kearifan Lokal, Batik

\section{A. Pendahuluan}

Pendidikan merupakan proses untuk membawa perubahan yang diinginkan dalam perilaku manusia. Dengan kata lain pendidikan dapat didefinisikan sebagai suatu proses untuk memperoleh pengetahuan serta kebiasaan-kebiasaan melalui suatu pembelajaran atau sebuah studi. Pendidikan sebagai suatu upaya terencana dalam mengembangkan potensi peserta didik, sehingga diharapkan peserta didik memiliki kemampuan berpikir, nilai-nilai, moral, serta keyakinan yang diwariskan masyarakatnya. Oleh karena itu, pendidikan adalah sebuah proses pewarisan budaya serta karakter terhadap generasi muda sebagai generasi penerus tonggak peradaban berlangsungnya kehidupan. Sehingga melalui pendidikan, proses pengembangan budaya dan penanaman karakter yang berdasarkan nilai-nilai luhur bangsa dapat tercapai sebagaimana yang diharapkan (Rulam, 2014).

Karakter merupakan nilai-nilai perilaku manusia yang berhubungan dengan Tuhan Yang Maha Esa, diri sendiri, sesama manusia, lingkungan, dan kebangsaan yang terwujud dalam pikiran, sikap, perasaan, perkataan, dan perbuatan berdasarkan norma-norma agama, hukum, tata krama, budaya, dan adat istiadat. Pendidikan karakter adalah suatu sistem penanaman nilai-nilai karakter kepada warga Sekolah yang meliputi komponen pengetahuan, kesadaran atau kemauan, dan tindakan untuk melaksanakan nilai-nilai tersebut, baik terhadap Tuhan Yang Maha Esa, diri sendiri, sesama manusia, lingkungan, maupun kebangsaan sehingga menjadi manusia insan kamil.

Pelaksanaan pendidikan karakter di sekolah harus melibatkan semua komponen, termasuk komponen-komponen pendidikan itu sendiri, yaitu isi kurikulum, proses pembelajaran dan penilaian, kualitas hubungan, penanganan atau pengelolaan mata pelajaran, pengelolaan sekolah, pelaksanaan aktivitas atau 
kegiatan kokurikuler, pemberdayaan sarana prasarana, pembiayaan, dan etos kerja seluruh warga dan lingkungan sekolah (Masnur, 2018).

Komitmen nasional tentang perlunya pendidikan karakter, secara imperatif tertuang dalam Undang-undang Nomor 20 Tahun 2003 tentang Sistem Pendidikan Nasional pasal 3 UU tersebut dinyatakan bahwa:

"Pendidikan nasional berfungsi mengembangkan kemampuan dan membentuk watak serta peradaban bangsa yang bermartabat dalam rangka mencerdaskan kehidupan bangsa, bertujuan untuk berkembangnya potensi peserta didik agar menjadi manusia yang beriman dan bertakwa kepada Tuhan Yang Maha Esa, berakhlak mulia, sehat, berilmu, cakap, kreatif, mandiri, dan menjadi warga negara yang demokratis serta bertanggung jawab."

Tujuan pendidikan nasional di atas merupakan rumusan mengenai kualitas manusia Indonesia yang harus dikembangkan oleh setiap satuan pendidikan. Oleh karena itu, rumusan tujuan pendidikan nasional menjadi dasar dalam pengembangan pendidikan karakter. Pendidikan di setiap jenjang harus diselenggarakan secara sistematis guna mencapai tujuan tersebut. Hal ini berkaitan dengan pembentukan karakter peserta didik sehingga mampu bersaing, beretika, bermoral, sopan santun dan berinteraksi dengan masyarakat.

Urgensi karakter didasarkan pada hasil penelitian di Harvard University Amerika Serikat (Ali Ibrahim Akbar, 2000), yang menyimpulkan bahwa 20\% kesuksesan seseorang ditentukan oleh pengetahuan dan kemampuan teknis (hard skill), dan $80 \%$ ditentukan oleh kemampuan mengelola diri dan orang lain (soft skill). Bahkan orang-orang tersukses di dunia bisa berhasil dikarenakan lebih banyak didukung dengan kemampuan soft skill daripada hard skill. Hal mengisyaratkan bahwa mutu pendidikan karakter peserta didik sangat penting untuk ditingkatkan (Masnur, 2018).

Pendidikan karakter dapat dilaksanakan melalui keluarga, lingkungan masyarakat, dan juga sekolah. Sekolah sebagai sebuah lembaga pendidikan merupakan salah satu lembaga yang dianggap memiliki tanggung jawab terhadap pembentukan karakter anak (character building). Oleh sebab itu, sebagai sebuah lembaga, sekolah memiliki tanggung jawab moral untuk mendidik anak supaya pintar, cerdas, serta memiliki karakter yang baik sebagaimana diharapkan setiap orang tua. Sekolah bisa merespons hal tersebut dengan membumikan gagasan 
pendidikan karakter, yaitu melalui pengimplementasian gagasan pendidikan karakter melalui berbagai strategi untuk membentuk peserta didik yang berkarakter (Novan, 2013).

Pada prinsipnya, pengembangan budaya dan karakter bangsa tidak dimasukkan sebagai pokok bahasan, tetapi terintegrasi ke dalam mata pelajaran, pengembangan diri, dan budaya sekolah (Agus Zaenul Fitri, 2012). Oleh karena itu, pendidik dalam melakukan pembelajaran salah satu upaya yang dilakukan adalah memanfaatkan nilai-nilai kearifan lokal sebagai sumber pembelajaran untuk peserta didik. Menurut Poespowardojo (dalam Rahyono, 2015), local genius (kearifan lokal) memiliki ketahanan terhadap unsur-unsur yang datang dari luar dan mampu berkembang untuk masa-masa mendatang. Kepribadian suatu masyarakat ditentukan oleh kekuatan dan kemampuan local genius dalam menghadapi kekuatan dari luar. Jika local genius hilang atau musnah, maka kepribadian bangsa pun memudar.

Kearifan lokal merupakan nilai-nilai yang dianggap berharga bagi sebuah masyarakat yang tercermin dalam sikap dan perilaku sehari-hari masyarakatnya dan mewujud menjadi kepribadian yang menjadi ciri khasnya dan pembeda dengan masyarakat lokal lainnya. Kearifan lokal dapat dijadikan jembatan yang menghubungkan masa lalu dan masa sekarang, generasi nenek moyang dan generasi sekarang, demi menyiapkan masa depan dan generasi mendatang.

Kearifan lokal menjadi topik yang marak diperbincangkan seiring dengan kesadaran masyarakat akan pentingnya budaya lokal. Oleh karena itu, perlu ada upaya untuk terus menggali dan memproteksi kearifan lokal. Salah satu langkah yang dapat dilakukan adalah melalui pendidikan, baik pendidikan formal maupun non-formal. Muatan lokal dalam pendidikan (pembelajaran) harus dimaknai sebagai pengenalan diri dan lingkungan. Menggali dan menanamkan kembali kearifan lokal melalui pembelajaran merupakan bagian dari upaya membangun identitas bangsa dan dapat dijadikan sebagai sarana dalam menyeleksi pengaruh budaya yang datang dari luar. Dalam kearifan lokal terkandung nilai-nilai positif yang baik untuk dikembangkan dalam pembentukan karakter dan identitas bangsa (Wiyani, 2013). 
Lembaga pendidikan, khususnya Madrasah Ibtidaiyah tentunya harus ada upaya yang serius dari para pengelola untuk mencoba mendasarkan pola pembelajaran yang ada di dalam sebuah lembaga dengan keunggulan-keunggulan lokal yang bersanding dengan lembaga pendidikan tersebut. Dalam hal membentuk karakter anak didik, maka kearifan lokal tersebut akan menjadi semacam pembimbing yang akan membimbing anak untuk menemukan karakter dirinya yang selaras dengan pola pemikiran, gerak langkah dan budaya yang berkembang pada daerah dimana anak tersebut tinggal dan mengembangkan diri.

Menurut teori hukum ekologi terdapat hubungan timbal-balik antara lingkungan dengan tingkah laku. Lingkungan dapat mempengaruhi tingkah laku atau sebaliknya, tingkah laku juga dapat mempengaruhi lingkungan.Lingkungan tersusun atas struktur-struktur yang saling mempengaruhi di mana dalam strukturstruktur tersebut terdapat setting-setting tertentu pula.

Satu hal yang menarik dari teori ini adalah pengakuan adanya set tingkah laku (behavioral setting) yang dimaksud di sini adalah set tingkah laku kelompok (bukan tingkah laku individu) yang terjadi sebagai akibat kondisi lingkungan tertentu (physical milleu) (Sarlito, 2016). Dengan demikian, dengan menggunakan pendekatan teori human ecology dapat disimpulkan bahwa kearifan lokal muncul sebagai reaksi kelompok terhadap lingkungannya sehingga terjadi keseimbangan hidup dalam kelompok tersebut.

Jadi terbentuknya kearifan lokal merupakan hasil proses dialektika antara individu dengan lingkungannya. Kearifan lokal merupakan respon individu terhadap kondisi lingkungannya. Pada aras individu, kearifan lokal muncul sebagai hasil dari proses kerja kognitif individu sebagai upaya menetapkan pilihan nilainilai yang dianggap paling tepat bagi mereka. Pada aras kelompok, kearifan lokal merupakan upaya menemukan nilai-nilai bersama sebagai akibat dari pola-pola hubungan (setting) yang telah tersusun dalam sebuah lingkungan.

Berdasarkan pembahasan di atas dapat disimpulkan bahwa Batik Giriloyo merupakan salah satu bentuk kearifan lokal yang harus dijaga, dihormati dan dilestarikan di masa kini. Bahkan saat ini Batik Giriloyo telah menjadi produk unggulan di wilayah Wukirsari, Imogiri, Bantul. Hal ini tentu saja memicu sekolah-sekolah di wilayah tersebut untuk melestarikan budaya warisan nenek 
moyang tersebut, khususnya kepada generasi muda. Hal tersebut dilakukan dengan harapan bahwa keterampilan membatik dapat diwariskan kepada para generasi muda tersebut.

Salah satu contohnya adalah MI Maarif Giriloyo I. Madrasah ini telah memasukkan batik dalam kegiatan proses belajar mengajar. Kegiatan tersebut direspon baik oleh para murid yang dengan antusias mengikuti pembelajaran tersebut. Meskipun produk yang dihasilkan belum sepenuhnya memuaskan tetapi paling tidak sekolah ikut berperan aktif dalam mengenalkan budaya dan keterampilan membatik pada generasi muda.

\section{B. Metode Penelitian}

Penelitian ini merupakan penelitian deskriptif kualitatif. Data yang dikumpulkan bukan berupa angka-angka, melainkan naskah wawancara, catatan lapangan, dokumen pribadi, catatan, memo, dan dokumen resmi lainnya sehingga yang menjadi tujuan dari penelitian kualitatif ini adalah ingin menggambarkan realita empirik di balik fenomena secara mendalam, rinci dan tuntas. Oleh karena itu penggunaan pendekatan kualitatif dalam penelitian ini adalah dengan mencocokkan antara realita empirik dengan teori yang berlaku dengan menggunakan metode deskriptif (Moleong, 2018).

Jenis pendekatan yang digunakan untuk peneliti adalah pendekatan psikologi pendidikan, yaitu suatu pendekatan yang menggunakan penerapan psikologi dan metode-metode psikologi untuk studi perkembangan, belajar, motivasi belajar, pengajaran, asesmen, dan aspek psikologis lainnya berkaitan dengan proses belajar dan pembelajaran (Syamsul Bachri Thalib, 2017). Subjek penelitian adalah Kepala Sekolah, guru mata pelajaran batik, Pengawas Sekolah serta siswa kelas V berjumlah 23 siswa dan kelas VI berjumlah 18 siswa.

Metode pengumpulan data menggunakan wawancara, observasi, dan dokumentasi. Menurut Miles and Huberman (dikutip oleh Sugiyono, 2013), mengemukakan bahwa aktivitas dalam analisis data kualitatif dilakukan secara interaktif dan berlangsung secara terus menerus sampai tuntas, sehingga datanya sudah jenuh. Aktivitas dalam analisis data, yaitu: 1) data reduction (reduksi data) berarti merangkum, memilih hal-hal yang pokok, memfokuskan pada hal-hal yang 
penting, dicari tema dan polanya; 2) data display (penyajian data), dilakukan dalam bentuk uraian singkat, bagan, hubungan antar kategori, flowchart dan sejenisnya. Yang paling sering digunakan untuk menyajikan data adalah dengan teks yang bersifat naratif; 3) conclusion drawing/verification (penarikan kesimpulan/verifikasi).

\section{Hasil dan Pembahasan}

\section{Pembelajaran Berbasis Kearifan Lokal Membatik}

Pembelajaran merupakan upaya sistematis dan disengaja oleh pendidikan untuk menciptakan kondisi agar peserta didik melakukan kegiatan. Belajar mengajar sebagai sebuah proses dapat mengandung dua pengertian, yaitu rentetan tahap atau fase dalam mempelajari sesuatu dan dapat pula berarti sebagai rentetan kegiatan perencanaan oleh guru, perencanaan kegiatan sampai evaluasi dan program tindak lanjut (Suryosubroto, 2009).

Proses pembelajaran merupakan kegiatan paling pokok dalam keseluruhan proses pendidikan, sebab berhasil tidaknya pendidikan tergantung bagaimana proses belajar yang terjadi pada seseorang setelah berakhirnya melakukan aktivitas belajar. Pembelajaran dalam pendidikan karakter mengarah pada penguatan dan pengembangan perilaku anak secara utuh yang didasarkan/dirujuk pada suatu nilai. Penguatan adalah upaya untuk melapisi suatu perilaku anak sehingga berlapis (kuat).

Pengembangan perilaku adalah proses adaptasi perilaku anak terhadap situasi dan kondisi baru yang dihadapi berdasarkan pengalaman anak. Kegiatan penguatan dan pengembangan didasarkan pada suatu nilai yang dirujuk. Artinya, proses pendidikan karakter adalah proses yang terjadi karena didesain secara sadar, bukan suatu kebetulan.

Pengembangan karakter siswa yang dilakukan MI Maarif Giriloyo I senantiasa mengusahakan adanya paradigma baru lembaga pendidikan yang menjadikan filosofi hidup masyarakat Giriloyo sebagai pedoman bagi pengembangan karakter religius anak didiknya, agar nantinya anak didik yang ditempa di MI Maarif Giriloyo I bisa menjadi penerus dan penjaga kebudayaan masyarakat Giriloyo. Dalam rangka nasional, desain pendidikan karakter 
dengan pendekatan kearifan lokal sebuah daerah akan menjadi penguat program pendidikan karakter yang telah dicanangkan oleh pemerintah.

Pembentukan karakter harus dilakukan secara sistematis dan berkesinambungan yang melibatkan aspek "knowing, feeling, loving, dan action. Pembentukan karakter dapat diibaratkan sebagai pembentukan seseorang menjadi body builder (binaragawan) yang memerlukan "latihan otot-otot akhlak" secara terus-menerus agar menjadi kokoh dan kuat.

Karakter bisa tumbuh berkembang secara alami sebagaimana kondisi lingkungan yang melingkupinya. Namun, karakter yang berkembang secara alami ini belum tentu baik dan positif, karena sangat tergantung pada situasi dan kondisi yang ada. Oleh karena itulah perlu adanya suatu strategi guna mengembangkan karakter sebagaimana diperlukan oleh masyarakat, bangsa dan negara (Darmiyati Zuchdi, 2011).

Salah satu bentuk strategi guna mengembangkan karakter adalah melalui kearifan lokal. Ketika kearifan lokal menjadi bagian integral dalam sebuah pembelajaran, maka salah satu yang menjadi tujuan pokok pembelajaran adalah menghantarkan anak untuk mengkonstruksi nilai-nilai kearifan lokal pada dirinya, sebagai pijakan kehidupan di masa yang akan datang.

Pendidikan karakter berbasis kearifan lokal dapat digunakan sebagai media untuk melestarikan potensi masing-masing daerah. Kearifan lokal harus dikembangkan dari potensi daerah. Potensi daerah merupakan potensi sumber daya spesifik yang dimiliki suatu daerah tertentu.

\section{a. Perencanaan Pembelajaran Berbasis Kearifan Lokal Membatik}

Perencanaan pembelajaran merupakan pokok acuan dan panduan penyajian pembelajaran bagi anak agar maksimal dalam melaksanakan sebuah proses pembelajaran, sedang bagi orang tua dengan adanya perencanaan pembelajaran mereka akan tahu tentang bagaimana desain pembelajaran yang akan disajikan di kelas dalam proses perkembangan belajar anak.

Sebagaimana wajarnya penyelenggara pendidikan lainnya, pengelola MI Maarif Giriloyo I juga membuat perencanaan pembelajaran dalam wujud perangkat pengajaran, mulai dari program tahunan, program semester, silabus dan rencana pelaksanaan pembelajaran. Dalam setiap komponen perencanaan 
pembelajaran memuat nilai-nilai karakter sehingga dapat dijadikan acuan atau pedoman baik bagi pengelola, guru dan orang tua dalam menjalankan dan mengawasi pembelajaran anak.

Tahap perencanaan pembelajaran berbasis kearifan lokal di MI Maarif Giriloyo I menggunakan kurikulum muatan lokal batik yang terdiri dari program tahunan, program semester, silabus, dan RPP sebagai pedoman dalam pelaksanaan pembelajaran. Pada tahap ini program tahunan, program semester, silabus, dan RPP dirancang agar muatan maupun kegiatan pembelajarannya memfasilitasi/berwawasan pendidikan karakter.

\section{b. Pelaksanaan Pembelajaran Berbasis Kearifan Lokal Membatik}

Pelaksanaan pembelajaran di kelas terdiri atas kegiatan pendahuluan, inti, dan penutup dipilih dan dilaksanakan agar peserta didik mempraktikkan nilainilai karakter yang ditargetkan.

Kegiatan pendahuluan dimulai dengan berdoa bersama. Ketika melaksanakan aktivitas doa semua anak diajarkan untuk menengadahkan kedua tangan ke atas, sikap sederhana ini diajarkan oleh guru untuk melatih anak membiasakan diri dengan perilaku religius.

Kegiatan inti menjadi kegiatan yang paling terkonsep dengan rapi dalam RPP, baik metode, media maupun konten pembelajaran. Pengembangan karakter mulai dari tahap moral knowing (pengetahuan), moral feeling (perasaan), moral action (tindakan) dapat diintegrasikan melalui kegiatan inti yang terbagi atas eksplorasi, elaborasi, dan konfirmasi. Tahap moral knowing diintegrasikan melalui kegiatan eksplorasi. Moral knowing diorientasikan pada penguasaan pengetahuan tentang nilai-nilai, sedangkan dalam kegiatan eksplorasi peserta didik difasilitasi untuk memperoleh pengetahuan dan keterampilan serta mengembangkan sikap melalui kegiatan pembelajaran yang berpusat pada siswa.

Hal ini dapat dilihat dari komponen materi pelajaran batik, misal dengan mempelajari sejarah batik, teori pembuatan batik, pengetahuan tentang motif dan jenis-jenis batik. Tahap moral feeling diintegrasikan melalui kegiatan elaborasi. Pengembangan moral feeling pada kegiatan elaborasi merupakan penguatan aspek emosi peserta didik untuk menjadi manusia yang berkarakter. 
Penguatan ini berkaitan dengan bentuk-bentuk sikap yang harus dirasakan oleh peserta didik, antara lain kepekaan terhadap derita orang lain, pengendalian diri, kerendahan hati.

Dalam praktik pembatikan, peserta didik dilatih untuk merasakan efek dari perbuatan baik yang dia lakukan, sehingga jika kecintaan ini sudah tertanam maka hal ini akan menjadi kekuatan yang luar biasa dari dalam diri anak untuk melakukan kebaikan dan mengerem perbuatan negatif. Jadi, nilainilai karakter dalam kegiatan tersebut antara lain: kesabaran, ketelitian, dan kreatif tercermin pada proses pembuatan batik yang membutuhkan waktu lama dan imajinasi yang tinggi serta cinta tanah air sebagai bentuk rasa syukur dan penghargaan atas segala anugerah dan ciptaan Allah SWT.

Sementara tahap moral action melalui kegiatan konfirmasi berupa pemberian umpan balik positif dan penguatan dalam bentuk lisan, tulisan, isyarat, maupun memfasilitasi peserta didik melakukan refleksi untuk memperoleh pengalaman belajar yang telah dilakukan. Kegiatan konfirmasi dalam pembelajaran batik dilakukan guru dengan meminta siswa mengumpulkan hasil karya mereka dan menunjukkan pada siswa yang lain.

\section{c. Evaluasi Pembelajaran Berbasis Kearifan Lokal Membatik}

Ada beberapa teknik penilaian yang dapat digunakan untuk menilai pencapaian peserta didik baik dalam hal pencapaian akademik maupun kepribadian. Teknik-teknik tersebut melalui observasi, penilaian diri, dan penilaian antarteman

Evaluasi terhadap tumbuh kembang suatu karakter pada anak bukanlah suatu hal yang mudah, tetapi tidak berarti hal ini suatu yang mustahil untuk dilakukan oleh guru. Evaluasi karakter merupakan upaya untuk mengidentifikasi perkembangan capaian hirarki perilaku (berkarakter) dari waktu ke waktu melalui suatu identifikasi atau pengamatan terhadap perilaku yang muncul dalam keseharian anak.

Karakter tidak dapat dinilai dalam satu waktu, tetapi harus diobservasi dan diidentifikasi secara terus menerus dalam keseharian anak, baik di kelas, sekolah maupun rumah. Karena itu, penilaian karakter harus melibatkan tiga komponen tersebut. Evaluasi di kelas melibatkan guru, peserta didik sendiri, 
dan peserta didik lainnya. Evaluasi di sekolah melibatkan peserta didik, temanteman, guru, (termasuk Kepala Sekolah), penjaga sekolah, tenaga administrasi sekolah. Sedangkan di rumah melibatkan peserta didik dan orang tuanya.

\section{Nilai Karakter Religius dalam Pembelajaran Berbasis Kearifan Lokal Membatik}

Pengembangan nilai karakter religius berbasis kearifan lokal batik di MI Maarif Giriloyo I antara lain: pertama,melalui penciptaan motif batik sebagai pesan dan doa atau harapan yang ditujukan kepada Allah SWT, dapat juga diungkapkan melalui pola maupun warna yang digunakan dalam batik klasik khususnya corak Yogyakarta menerangkan bahwa dalam kehidupan manusia selalu terikat oleh simbol-simbol yang mencerminkan kehidupannya.

Seperti contoh pada motif batik wahyu tumurun. Motif wahyu tumurun telah dikenal sejak tahun 1480 di wilayah Jogjakarta. Motif ini lalu menyebar ke berbagai daerah. Di masing-masing daerah inilah wahyu tumurun mengalami perkembangan variasi motif. Di Yogyakarta, motif burung yang biasa digunakan adalah burung merak. Burung merak dianggap sebagai simbol lokal Yogyakarta yang menunjukkan asal motif batik.

Penggambaran pola dalam motif batik wahyu tumurun tentu tidak dibuat dengan tanpa makna. Pola mahkota terbang yang menjadi motif utama, menyimbolkan kemuliaan. Filosofinya menggambarkan pengharapan agar para pemakainya mendapat petunjuk, berkah, rahmat, dan anugerah yang berlimpah dari Tuhan Yang Maha Kuasa. Pengharapan untuk mencapai keberhasilan dalam meraih cita-cita, kedudukan ataupun pangkat. Sedangkan dalam hal khusus seperti pernikahan, motif ini menyiratkan berkah kehidupan lahir batin dalam kehidupan berumah tangga, keharmonisan dan kebahagiaan yang langgeng dan terjaga selama-lamanya.

Kedalaman makna kehidupan rumah tangga inilah yang membuat motif wahyu tumurun dipilih sebagai motif khusus yang sering dikenakan dalam upacara pernikahan adat Jawa, yaitu waktu midodareni (malam sebelum hari pernikahan) (Adi Kusrianto, 2015). Adapun gambar batik motif wahyu tumurun sebagai berikut: 


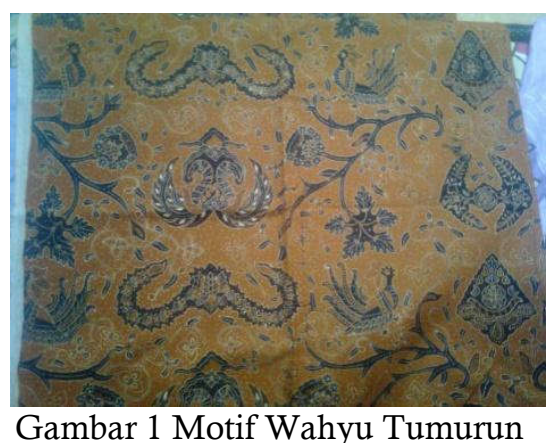

Motif lainnya adalah motif batik Truntum. Truntum adalah motif alam, yaitu dari bintang-bintang di langit. Truntum artinya mengumpulkan harta benda. Warna yang digunakan adalah soga (coklat). Motif ini sering dipakai untuk upacara pernikahan (Sri Wiji Lestari, dkk., 2013).

Motifnya sederhana seperti taburan bunga-bunga abstrak kecil, seperti kuntum bunga melati, atau seperti bintang yang bertaburan di langit. Batik motif truntum biasanya dipakai oleh orang tua pengantin pada hari pernikahan. Harapannya adalah agar cinta kasih yang tumaruntum ini akan menghinggapi kedua mempelai. Terkandung makna "ing ngarsa sung tuladha", orang tua sudah lulus dari ujian cinta kasih, hingga layak dan wajib menuntun kedua mempelai memasuki kehidupan baru.Orang tua mempelai berharap agar cinta kasih yang tumaruntum tersebut akan tumurun kepada mempelai kebanggaannya, perwujudan sikap "tut wuri handayani". Sebuah rangkaian keteladanan dan doa pengharapan tersimbolkan melalui motif truntum (Riyanto, dkk., 1997). Adapun gambar batik motif Truntum sebagai berikut:

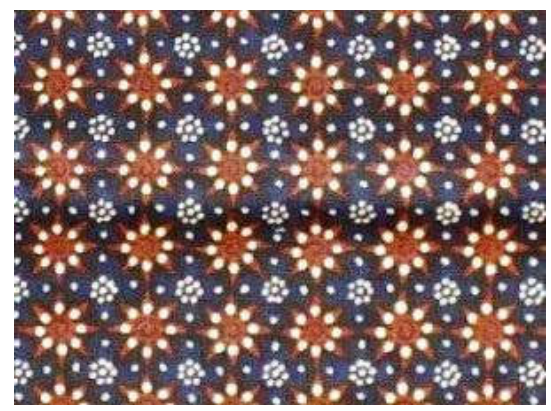

Gambar 2 Motif Truntum

Kedua, pengembangan karakter religius siswa terintegrasi dalam pelaksanaan pembelajaran di kelas terdiri atas kegiatan pendahuluan, inti, dan penutup. Dalam kegiatan inti, pengembangan moral knowing diintegrasikan melalui kegiatan eksplorasi dengan belajar sejarah batik, teori pembuatan batik, motif dan jenis-jenis batik beserta makna simbolisnya. Nilai karakter religius 
yang dapat dikembangkan antara lain iman dan takwa dengan mengagumi kebesaran Sang Pencipta yang sangat indah segala ciptaanNya, rasa syukur disertai penghargaan terhadap hasil budaya nasional.

Pengembangan moral feeling diintegrasikan dalam kegiatan elaborasi akan terbentuk nilai-nilai karakter religius antara lain: kesabaran, ketelitian, dan kreatif tercermin pada proses pembuatan batik yang membutuhkan waktu lama dan imajinasi yang tinggi serta cinta tanah air sebagai bentuk rasa syukur dan penghargaan atas segala anugerah dan ciptaan Allah SWT. Sedangkan pengembanganmoral action melalui kegiatan konfirmasi, adapun nilai-nilai karakter religius yang dikembangkan antara lain insyirah berupa penghargaan terhadap karya-karya orang lain, al-tawadlu berupa sikap rendah hati apabila menghasilkan karya batik yang bagus, al-munfiqun tercermin dengan adanya kerjasama dan toleransi dengan teman kelompoknya apabila ada tugas yang harus diselesaikan secara kelompok.

\section{Kesimpulan}

Proses pembelajaran berbasis kearifan lokal batik di MI Maarif Giriloyo I dilaksanakan mulai dari tahap perencanaan, pelaksanaan, dan evaluasi pembelajaran. Tahap perencanaan pembelajaran meliputi program tahunan, program semester, silabus, dan RPP. Tahap pelaksanaan pembelajaran terdiri atas kegiatan pendahuluan, inti (meliputi eksplorasi, elaborasi, konfirmasi), dan penutup. Sedangkan tahap evaluasi pembelajaran melalui observasi, penilaian diri, dan penilaian antar teman. Nilai-nilai karakter religius yang dikembangkan dalam pembelajaran berbasis kearifan lokal batik di MI Maarif Giriloyo I antara lain: pertama, melalui penciptaan motif batik sebagai pesan dan doa atau harapan yang ditujukan kepada Allah SWT, dapat juga diungkapkan melalui pola maupun warna yang digunakan dalam batik klasik khususnya corak Yogyakarta menerangkan bahwa dalam kehidupan manusia selalu terikat oleh simbol-simbol yang mencerminkan kehidupannya. Kedua, pengembangan karakter religius siswa terintegrasi dalam pelaksanaan pembelajaran di kelas terdiri atas kegiatan pendahuluan, inti, dan penutup.

$* * * * * * * * *$ 


\section{Daftar Pustaka}

Ahmadi, R. (2014). Pengantar Pendidikan Asas dan Filsafat Pendidikan.Yogyakarta: ArRuzz Media.

Azwar, S. (2017). Metode Penelitian Psikologi Edisi II, Yogyakarta: Pustaka Pelajar.

Fitri, A. Z. (2012). Reinventing Human Character: Pendidikan Karakter Berbasis Nilai dan Etika di Sekolah, Yogyakarta: Ar-Ruzz Media.

Kusrianto, A. (2015). Batik: Filosofi, Motif dan Kegunaan, Bandung: Andi Publisher.

Lestari, S. W. dkk. (2013). Pendidikan Batik untuk Kelas III SD dan MI, Solo: PT Tiga Serangkai Pustaka Mandiri.

Moleong, L. J. (2018). Metodologi Penelitian Kualitatif, Bandung: PT Remaja Rosda Karya.

Muslich, M. (2018). Pendidikan Karakter: Menjawab Tantangan Krisis Multidimensional, Jakarta: Bumi Aksara.

Rahyono, F.X. (2015). Kearifan Budaya dalam Kata, Jakarta: Wedatama Widya Sastra.

Riyanto, dkk., (1997). Katalog Batik Indonesia, Yogyakarta: Balai Besar Penelitian dan Pengembangan Industri Kerajinan dan Batik Proyek Pengembangan dan Pelayanan Teknologi Industri Kerajinan dan Batik.

Sarwono, W. S. (2016). Psikologi Lingkungan dan Pembangunan, Jakarta: Mitra Wacana Media.

Sugiyono. (2019). Metode Penelitian Kuantitatif, Kualitatif dan R\&D, Bandung: ALFABETA.

Suryosubroto, B. (2009). Proses Belajar Mengajar di Sekolah (Edisi Revisi), Jakarta: Rineka Cipta.

Thalib, S. B. (2017). Psikologi Pendidikan Berbasis Analisis Empiris Aplikatif, Jakarta: Prenada Media Grup.

Wiyani, N. A. (2013). Konsep, Praktik, dan Strategi Membumikan Pendidikan Karakter di $S D$. Yogyakarta: Ar-Ruzz Media.

Zuchdi, D. (2011). Pendidikan Karakter dalam Perpektif Teori dan Praktek, Yogyakarta: UNY Press. 